\title{
HERODOTUS AND THE 1820 SETTLERS IN SOUTH AFRICA: HISTORIOGRAPHIES OF COLONIZATION AND THE 'CACOPHONY OF VOICES'
}

\author{
M Lambert, Research Associate, SOLL (Rhodes University)
}

\begin{abstract}
The renewal of interest in Herodotus as an effective and creative historian within a predominantly oral tradition has been a feature of prolific research during the last twenty years. In the very year in which the arrival of the 1820 settlers in the east of the former Cape Colony in South Africa is being remembered, and even commemorated, I attempt a reading of Herodotus' celebrated account of the Greek colonization of Cyrene in Libya (North Africa) through the historiographical lens of accounts of the arrival of these British settlers, focussing on the narratives of colonization common to these exempla more than two millennia apart. My intention is to continue the conversation, especially amongst South African classicists, about how to tackle the thorny question of decolonizing the content and teaching of the Classics in our universities.
\end{abstract}

Keywords: 1820 settlers; colonization; Herodotus; Cyrene; Libya; postcolonial historiography.

2020 marks the $200^{\text {th }}$ anniversary of the arrival in the Cape Colony of the 1820 settlers from Britain. How historians interpret the arrival of these settlers and their subsequent colonization of areas in the east of the Cape Colony raises the problem of sources: which sources are written, which are oral, where do they originate, and how does the historian integrate the two when the written is often the voice of the colonizer and the oral that of the colonized.

As one cannot speak meaningfully about decolonization without an understanding of colonization, my intention is to demonstrate how decolonizing the teaching of the Classics in our universities can use Herodotus effectively by analyzing narratives of colonization and the attendant problem of sources, evident in much South African historiography of the colonial period. In conclusion, I suggest that Herodotus could be regarded as the father of postcolonial historiography as well.

\section{The 1820 settlers in South Africa: Historiographies of colonization}

On the $15^{\text {th }}$ May 1820, a Royal Navy ship, the Weymouth, arrived in Algoa Bay: on board was the Pedlar family from North Petherwin in Cornwall, my ancestors on my paternal grandmother's side. In order to mark the bicentenary of the arrival of 
the 1820 settlers in South Africa, I offered to write an article on my family's settler heritage for the local newspaper (The Witness, published in Pietermaritzburg, KwaZulu-Natal). In response to my offer, the editor requested that the article be 'postcolonial', i.e. neither triumphalist nor univocal. The article had to include the voice(s) of the indigenous peoples, the original inhabitants of the eastern part of the Cape Colony. ${ }^{1}$

There are certainly books and articles about the turbulent history of the Eastern Cape, published during the last twenty years or so, including analyses of the 1820 settlers, which could be considered 'postcolonial' in the sense that the voices of colonial authority, military power and the settlers themselves are not privileged at the expense of the voices of the indigenous peoples.

The most recent, John Laband's The land wars (2020), subtitled The dispossession of the Khoisan and AmaXhosa in the Cape Colony situates the arrival of the 'Albany settlers' within the grim context of the Cape Frontier Wars, ${ }^{2}$ the violent dispossession of the indigenous peoples of their land, and South Africa's current restorative land reform process. Laband's two introductory chapters (The AmaXhosa and the San, The Khoikoin and the AmaXhosa) indicate at the outset what historiographical position his work will adopt, a position developed throughout his work by references to Xhosa myths and oral traditions, by his use of isiXhosa terms, and by his careful, almost Herodotean, attention to the genealogies of Xhosa chiefs, and to their spiritual and physical attachment to the mountains, valleys, rivers, forests and plains of the Eastern Cape.

Even more nuanced, from a theoretical standpoint, is a recent history of social and cultural relations in colonial Natal, in which $\mathrm{T} \mathrm{J}$ Tallie demonstrates what he understands by postcolonial historiography. As he claims in his introduction, 'Queering colonial Natal analyzes social relations in the colony while keeping its messy, multisided histories at the fore. I do this through a methodology that combines queer theoretical approaches with critical indigenous studies' (2019:4). For Tallie, queer theory gives him a theoretical basis for analyzing moments of disruption, which resist or 'queer' the colony's structures and

* My grateful thanks to the indulgent editors of Akroterion and to the very attentive readers of this article, who updated the bibliography and thus immeasurably improved what was originally devised as a general talk to be offered to the Heritage Society in Pietermaritzburg in 2020.

1 Lambert 2020:7. The article was given full-page prominence opposite the editorial page. The headline is 'The story of a family who travelled to Africa'; the title of the article, 'The 1820 settlers bicentenary: A settler family's heritage'.

2 Laband revives the use of 'Cape Frontier Wars', but does note, with approval, the use of other terms such as 'Wars of dispossession and resistance in the Eastern Cape' and 'Cape-Xhosa wars' (2020:5). 
normative values, whereas 'an indigenous studies-centred approach within a settler colonial framework allows room for reading forms of resistance and challenge while foregrounding the significant power disparities that operated in European settler relations with indigenous Africans (as well as Indian migrants) in Natal' (2019:6).

Postcolonial versions of history, like Tallie's, are neither univocal nor do they make any claim to a kind of panoptic 'objectivity', but take into account the plurality of voices in both written texts and oral traditions - in postcolonial histories of colonialism, especially, discourses in both the metropole (the colonizing power) and the periphery (the colony) are analyzed to examine how the one is present in the other, and how the subjectivities of the people involved (the author included) are shaped or not shaped by imperialist ideologies.

In contrast, colonization narratives, particularly those written in family histories by descendants of the original 1820 settlers, ${ }^{3}$ often seem to be structured, rather formulaically, as follows: i) justificatory reasons for emigration from the metropole; ${ }^{4}$ (ii) the composition of the first party of settlers, usually from a socioeconomic standpoint; ${ }^{5}$ (iii) details of the journey from fatherland or mother-city to the new destination, in which the privations of the settlers are highlighted; ${ }^{6}$ (iv) the dramatic arrival of the settlers in the new country and further privations as the settlers begin to build their first settlements; ${ }^{7}$ (v) the tensions which arise between the settlers and the metropole, ${ }^{8}$ and between the settlers and the indigenous peoples, often deployed by the settler historian to construct settler myths of a

3 See, for example, Snell 2004, which makes use of other 1820 settler histories (2004:143-145).

4 Snell foregrounds the economic recession in Europe (2004:3).

5 The Colonial Office's assessments for membership of emigrating 'parties' were based entirely on financial means (ibid. 3-4).

${ }^{6}$ The journey of the Weymouth from Portsmouth to Algoa Bay took more than four months; Elizabeth Pedlar gave birth to her fourth child during the journey; there was no established port in Algoa Bay; women and children had to be carried ashore by British troops and initial accommodation was provided for the settlers in a sprawling tent town (ibid. 3-6).

7 Boer ox-wagons were requisitioned to transport the settlers to their new homes in 'Albany' on the Brak River; the settlers had to build their own houses of 'sod and wattle' on the twenty acres allotted to them or their 'party's' leader if he had paid their fares (Snell 2004:6-7). Cf. Laband's one hundred acres per adult male (2020:151).

8 The settlers did not know that they were to be placed between the Fish and Bushmans Rivers to constitute a buffer zone between the Cape Colony and the amaXhosa whom British troops had cleared out of this area to pave the way for the British settlers (Snell 2004:3-9). 
heroic frontier existence, ${ }^{9}$ forged against enormous odds, including the duplicity and mendacity of the metropole or imperialist colonizers 'back home'; (vi) inevitably, as the settlers' crops fail, or as they experience famine, disease and penury, land-grabs occur beyond the original settlement and in territories which settlers may think belong to nobody (the myth of the Terra nullius), but which in fact belong to indigenous peoples; ${ }^{10}$ (vii) wars between the settlers and the indigenous peoples over settler expansionism $;{ }^{11}$ (viii) the resolution of the conflicts, either by the victories of the settlers, often mythologized in a crude triumphalism, which ushers in settler dynasties and landed estates with names recalling the metropole, or the (rare) victories of the indigenous peoples, who expel the settlers and reclaim the violently appropriated lands. ${ }^{12}$

\section{The source problem}

Because the above exemplum is a family history, written for a specific readership, the author has clearly tailored his account to the expectations of his audience. There is no sustained critique of the British imperialist project, nor any in-depth exploration of who the indigenous peoples were and what lands they owned. Snell mentions the Xhosa Wars (note the nomenclature) only in as much as they impinge on the lives and livelihoods of the settlers, but does acknowledge that in 1811-

9 Exemplified for instance, in Thomas Pringle's 'epistle in rhyme', The emigrant's cabin (begun in 1822 and published in 1834). An extract appears on the base of the 1820 Settlers Monument in Grahamstown (now Makhanda).

10 The British colonial authorities had not surveyed the suitability of the area for agriculture and had misled the settlers with lies about its 'verdant' fertility. As many of the settlers knew very little about agriculture, their first crops failed and there was widespread famine, especially in the early years after their arrival. Many abandoned the original settlements (Snell 2004:7-8). But $c f$. Laband's claim that the Governor of the Cape himself, Lord Charles Somerset, had been fooled by the 'verdant landscape' after recent rains (2020:153).

11 Four of the nine Xhosa wars (1834-1878), or the Cape Frontier Wars (see n.2), took place after the arrival of the 1820 settlers in response to their quest for new land in areas which were traditional Xhosa grazing lands (ibid. 8-15). Lambert, including the rebellion of 1880, adds that the Hundred Years war on this frontier (1779-1880) make this one of the deadliest conflicts in the grim history of colonization in Africa (2020:7).

12 The sentiments expressed in Henry Pedlar's obituary (The Grahams Town Journal $27^{\text {th }}$ August 1866) are a notable example of British colonial triumphalism (Snell 2004:1517); the names of the 1820 settler farms associated with the Pedlars reflect this (Somerset Farm, Rokeby Park, Elizabeth Farm, Cotticebrook, Waterfall, Hopewell) (ibid. 2004:8-15); Snell reproduces a copy of Henry Pedlar's will in which Pedlar establishes a landed settler dynasty on African soil, ibid. 141-142. For Xhosa victories over the British, see Laband 2020:206-207, 245 (Sandile's 'spectacular victory' over Somerset and his forces in 1846, and the military reputation of his brother, Maqoma). 
1812, Lieutenant-Colonel John Graham 'pushed the Xhosa out of the Zuurveld', thus paving the way for the land 'grants' offered to the 1820 settlers. ${ }^{13}$

Deep sympathy is aroused for the settler families, like the Pedlars, who worked hard, rented, bought, sold and so 'owned' the land conquered for them, even to the extent of bequeathing estates and mortgages to their children.

In many ways, accounts like these contribute to the myth-making surrounding the frontier settlers: similar myth-making is evident in narratives of the American West in which the frontiersman tames a demarcated patch of nature in a wilderness criss-crossed by marauding Amerindians. ${ }^{14}$ Underlying much of this myth-making is the subtext of (white) civilization and (black or nutbrown) barbarism.

Such myth-making, in its use of dramatic vignettes such as a woman giving birth in an Anglican church on Christmas Day, whilst marauding Xhosa braves outside burn, pillage and loot, implies a moral endorsement of the settlers' messianic mission, and justification for meeting the violence of barbarism with the structured violence of the military retaliation. ${ }^{15}$

What these family histories, in their reproduction of wills and mortgages, never investigate is who owned the land before it was 'granted' to the 1820 settlers, what 'ownership' meant to the communities involved, and what answers to these questions imply for the relationship between the descendants of these settler families and the indigenous peoples with whom they then lived. ${ }^{16}$ That we are still asking these questions two hundred years later is a sure sign that settler historians have not listened, or find it too uncomfortable to listen, to the 'cacophony of voices' which colonization has generated. Histories of the 1820 settlers, in order to be comprehensively and inclusively South African, need to analyse not only the written texts of the conquerors, but also the oral traditions of the conquered, and not privilege the written word above the oral. ${ }^{17}$ This 'source problem', however, in relation to colonization, is present at the very origins of western historiography itself.

13 2004:9. Cf. Laband 2020:126-130.

14 One need only think of the 'autobiographical' works of 'Buffalo Bill' Cody (18461917) and his successors in the genre, Zane Grey (1872-1939) and Louis L'Amour (1908-1988). The latter's 'How the West was won' (1963) represents the American apogee of this kind of settler myth-making. Closer to home, David Maughan Brown's 'Land, freedom and fiction' (1985) analyses an especially virulent form of settler mythmaking in relation to the Mau Mau uprisings in colonial Kenya.

15 See Snell's account of the Xhosa attack on St. John's Anglican Church in Bathurst in $1834(2004: 9)$.

16 These questions are, of course, investigated by Laband 2020 (a professional historian).

17 Similar arguments are made for the inclusion of oral poetic forms in anthologies of South African literature (see e.g. Brown 1998). 


\section{Herodotus and the source problem}

As Herodotus' mode of composition has often been the subject of scholarly speculation, ${ }^{18}$ so too has his use (or misuse, or even invention) of his sources. Too often the criticism has been of his historiography - as if the very pioneer of the novel prose genre of 'history' should have respected the primacy of (non-existent) written sources and should have subjected them to the same kind of criticism which scholars have levelled at his methodology!

Thankfully, Homeric scholarship on oral traditions and the comparative methodologies which this has engendered, together with the research of Vansina $(1961,1985,1994)$ and others into the importance of oral traditions in writing the histories of pre-colonial Africa, have aided scholars in understanding how Herodotus, researching in a predominantly oral culture, used oral traditions, which embody what Gould refers to as 'social memory', as his primary sources. ${ }^{19}$

Epic narrative (Homer), Greek tragedy, the choral verse of Pindar — the kinds of genre which are performative and refine the art of the storyteller - are amongst the important influences on Herodotus' primary sources, which give his Histories its narrative power and tragic trajectories. ${ }^{20}$ In many ways, Aristotle was right to designate Herodotus as a mythologos, a 'storyteller', but he was not merely this. $^{21}$

Like any modern researcher, Herodotus had his secondary sources as well, but these were not as heavily weighted as they are in a non-oral culture, occupying, as he did, that slippery interstitial space between oral composition and written

18 For a useful (and impressively succinct) survey of the debate (e.g. Jacoby as 'analyst', Immerwahr as 'unitarian' and Fornara's 'complementary' approach), see Dewald \& Marincola's 'Introduction' (2006:3). For Herodotus' episodic composition over a long period before the unification of the episodes for 'publication', see Thomas 2006:61. For the problematic use of 'publication' for a work designed for an audience, not a readership, see Gould 1989:17.

19 Cf. Gould 1989:27-41. For interrogation of the content of 'social memory' and the complexity of oral traditions themselves (what they contain, omit and why), see Malkin 2003:155-170; Baragwanath 2020:177-184. In the general introduction to their commentary, Asheri et al. note that Herodotus' oral sources are unlike those studied by 'modern anthropologists or Africanists', as they exist alongside writing which had been known for centuries (2007:16-17). Sadly, no reasons for this generalization are offered.

20 For the influence of epic, see Gould 1989:49-50; 60-62; Boedeker 2002:97-116. For tragedy, Saïd 2002:117-145; Griffin 2006:46-59 (cf. the influence of Herodotus on tragedy, Hall 1989:133-143); for Herodotus' performative style, see Bakker 2006:95; for the invention of sources and Fehling's important 1971 study, see Dewald \& Marincola 2006:4; for criticism of Fehling, see Griffiths 2006:137. On sources generally, see Asheri et al. 2007:15-23.

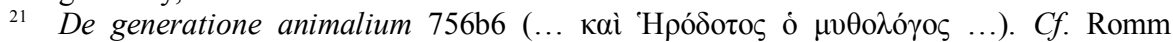
1998:11. 
texts. ${ }^{22}$ Herodotus certainly cites Greek, Middle Eastern (Persian, Lydian, Babylonian) and African (Egyptian) inscriptions, but whether he actually read any himself, or simply relied on hearsay accounts of them, is a matter of speculation. ${ }^{23}$ Logopoioi, such as Hecataeus of Miletus, who deliberately chose to reject the decorative 'fictions' of poetry by writing in an austere style worthy of 'scientific' subject-matter, such as the nature of the earth and the lineages of Greek families, were amongst the prose sources Herodotus very occasionally used, imitated and cited. $^{24}$

However, what makes Herodotus' work uniquely significant, is what Luraghi has deemed his meta-historie, that is, Herodotus' reflections on his methodology, on the process of historie itself, on how he gathered information and assessed its credibility, in a conversation he constantly keeps before us. ${ }^{25}$ Wellknown is Herodotus' methodology: the evidence of his own senses of sight and

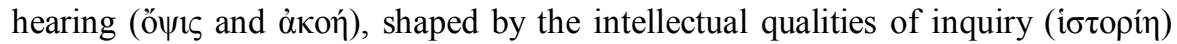
and considered opinion $(\gamma \vee \omega ́ \mu \eta)$, essential to the armoury of any postcolonial historian or anthropologist, let alone the pioneer historian in western civilization, collecting and assessing oral traditions. ${ }^{26}$ Noticeably absent is the rigorous critique of these alongside written texts.

Herodotus' meta-historie not only takes the form of methodological commentary in the first person, but he frequently uses the third person plural ('they say'), of entire communities, for example, the Spartans or the Egyptians or the Scythians or the Cyreneans, perhaps referring, as Giangiulio (2001) and Luraghi (2006) have rather generously suggested, ${ }^{27}$ to the logioi of these communities, memorializing their 'stories', or what they have remembered and considered as significant in their identity 'stories', and communicating them, via an interviewee(s), to the researcher - Herodotus' àkon in action. ${ }^{28}$

Thomas rightly believes that Herodotus' meta-historiē reveals 'his relation to very recent and contemporary intellectual trends' in, for instance the preSocratic, Ionian philosophers and some Hippocratic texts, and suggests, along with

22 Rösler 2002:79-94.

23 West 1985:278-305; Gould 1989:48. Cf. Asheri et al. 2007:17-18. .

24 For the very infrequent references to written sources, see e.g. 4.13-14, 5.59. Cf. How \& Wells 1961:20-27; Romm 1998:13-19; Hornblower 2002:373-386; Asheri et al. 2007:568-569. For Herodotus and the use of genealogies to shape the chronological structure of his Histories, see Gould 1989:45-47.

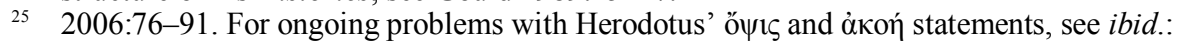
$81-85$.

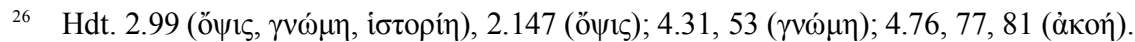

27 Rather than assuming, as some scholars have, that Herodotus simply invented them (Luraghi 2006:83). Cf. Armayor 1978:59-73; Chamberlain 2001:1.5-34.

28 Gould 1989:27 (on logioi); Malkin 2003:162, 165-170. 
Fowler, that Herodotus probably invented the 'problem of sources' and source criticism. ${ }^{29}$ A surely essential move for the foundation of the genre of historiē: Herodotus rightly deserves to be remembered as the 'father of history' and 'historiography'.

As we have suggested, any credible modern account, for instance, of the colonization of South Africa would have to assess the sources - both the records, opinions and subjective myth-making of the colonizers and the colonized. Herodotus, in fact, recognizes and appreciates that the history of colonization has multiple voices.

Luraghi's research uses as an important exemplum Herodotus' account of the Greek colonization of Cyrene in Africa, which has three important voices the Spartans, the Theraeans and the Cyrenaeans, descendants of the Theraeans, many of whom presumably intermarried with other colonists (such as the Phoenicians) and the indigenous peoples of Libya.

Herodotus points out, when he can, where the various accounts differ and draws our attention to one of the perennial features of colonization everywhere: the colonizers in the metropole (the Theraeans) have a different and more sanitised version of the process of founding and establishing the colony, whereas the settlers, who engage with the indigenous peoples, remember the problems experienced in the process (including violent rejection by the founding city), as well as a localized version of the genealogy of the founding hero (Battus). ${ }^{30}$ The account is worth examining in detail.

At the outset, it is salutary to remember, as Dewald and Marincola point out, that Herodotus' 'interest in ethnography' is 'not undertaken from the point of view of the imperialist aggressor [Persia], but rather from the point of view of the invaded people, the Greeks'. ${ }^{31}$ As Baragwanath perceptively observes, Persian treatment of the Greek colonies in Libya, including the enslavement of Barce, serves as a 'precursor and parallel' to the Persian invasion of Greece and what 'was on the cards' for the Greeks. ${ }^{32}$

Herodotus in Book Four certainly keeps an eye on the intention of his project as a whole given at the start of his enquiry:

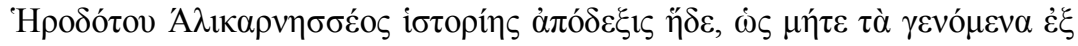

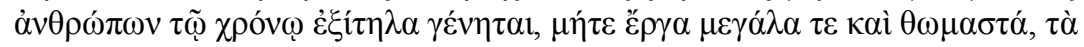

29 Thomas 2006:71. Cf. Gould 1989:7-11 on the influence of the thought-world of the Ionian philosophers on Herodotus; Raaflaub 2002:149-186; Asheri et al. 2007:55.

30 Luraghi 2006:80-82; cf. Asheri et al 2007:567-569.

31 Dewald \& Marincola 2006:9.

32 Baragwanath 2020:162. 


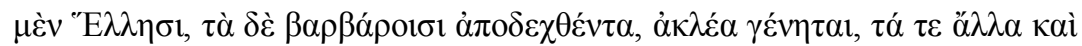
$\delta \iota^{\prime} \hat{\eta} v \alpha i \tau i ́ \eta v \dot{\varepsilon} \pi \mathrm{o} \lambda \dot{\varepsilon} \mu \eta \sigma \alpha v \dot{\alpha} \lambda \lambda \hat{\eta} \lambda \mathrm{ol \sigma l}(1.1)$

This is the product of the inquiry of Herodotus of Halicarnassus, composed in order that the great and wondrous achievements of both the Greeks and the barbarians, and especially why they made war on each other, should not be blotted out of human memory and be bereft of glory. ${ }^{33}$

Book Four opens with the reasons for Darius' campaign against the Scythians; after an extensive and entertaining social and cultural history of Scythia and its many peoples, ${ }^{34}$ he returns to Darius' campaign in chapter 118 . After a full account of this campaign, illustrating the successes of the Scythians and the Persian reliance on treacherous Ionians, like Histiaeus of Miletus, to escape from them (4.141-142), Herodotus introduces Libya as the next field for Persian ambitions. The 'digression' on the colonization of Cyrene and Libya and its peoples is thus framed by his focus on the Persians: we are reminded that the Libyan kings do not care about the Persian kings in any way at all (4.197) and that it was the Persians who came from Egypt to lay siege to Barce, the city founded by the Cyrenaeans (4.200), which they eventually took by a treacherous ruse (4.201).

Herodotus prefigures his account of the Greek (Theraean) colonization of Libya with a narrative of multiple migrations,${ }^{35}$ which, he claims, is supported by both Spartan and Theraean records (4.150), and which is characterized by some far-fetched ancestral claims, ${ }^{36}$ assumptions about rights to land, duplicity and power struggles, ${ }^{37}$ initiated by the settlers and furthered by intermarriage with the

33 See Bakker's interesting interpretation of the implications of the famous phrase,

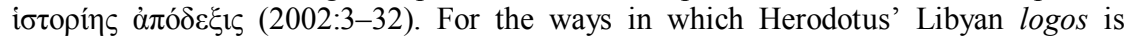
essential to the proem and 'overall design' of his work, see Baragwanath 2020:157-175. Translations from the Greek text (Hude 1975, repr.) are my own, unless otherwise indicated.

34 For an assessment of this, in the light of recent archaeology, see West 2002:437-456.

35 Minyae, descendants of the Argonauts, from Lemnos to Sparta; Cadmus, from Phoenicia to Thebes, with a significant stop on Kalliste (Thera); Theras, of Phoenician lineage, from Sparta to relatives on Kalliste, together with some troublesome Minyae (4.145, 147).

36 The Minyae, camping on Mt. Taygetus in Laconia, claimed that they had come home to the land of their fathers, none other than the Tyndaridae, Castor and Pollux, who were on the Argo (4.145); Theras claimed kinship with the descendants of Cadmus' party on the island of Kalliste, who had been there for eight generations (4.147).

37 The Minyae demanded a share in the Spartan kingship (4.146). Herodotus hints at another kind of power struggle behind Theras' reason for emigrating from Sparta to live amongst his $\sigma 0 \gamma \gamma \varepsilon v \varepsilon \varepsilon_{\alpha \varsigma}$ (kinsmen): Theras had been the regent to his nephews, the royal sons of Aristodemus but, when they became kings, he found being ruled, rather than ruling, difficult, and so decided to emigrate (4.147). 
locals, as a result of which, in one striking case, indigenous wives showed more loyalty to their immigrant husbands than to their fathers and brothers. ${ }^{38}$

What is notable is that Herodotus does not shrink from contrasting the morality of both the host community and the settlers. In contrast to the generosity of the Spartans, fully in keeping with the $\xi \varepsilon v i ́ \alpha$ which underpins Greek popular morality (4.145), the immigrant Minyans, for instance, displayed excessive hubris when they requested a share in the Spartan kingship and performed acts which were sacrilegious, thus disrespecting the religious norms of the host community. ${ }^{39}$ It is not difficult to detect pro-Spartan bias in the source Herodotus uses here. ${ }^{40}$

Theras's lineage, which Herodotus provides, immediately arouses the 'hermeneutic of suspicion'. We are informed that Theras is a descendant of the son and brother of Oedipus. ${ }^{41}$ When he set out for the island of Kalliste with a mixed party of Spartans (from each of the three Dorian phylai) and some fugitive Minyae, Herodotus is then at pains to indicate, presumably because he suspected that colonization could be morally problematic, that the intentions of Theras, which he may well have learned from a biased Theraean oral tradition, were morally sound: he wanted to avoid bloodshed in a conflict between the Spartans and the Minyae and desired to settle amongst the people on Kalliste and claim them as his own, rather than drive them out (4.148).

38 The hubris and impious activities of the Minyae resulted in their arrest and imprisonment by the Spartans, who decided to kill them. The Spartan jailers, in turn, were thwarted by the notoriously feisty and inventive wives of the Minyans, who were daughters of prominent Spartans: having been granted permission to visit their settler husbands in prison, the resourceful wives swopped clothes with their husbands, who promptly escaped in drag and returned to the site of their original encampment (4.146).

39 X

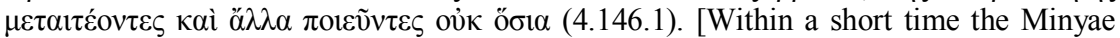
committed acts of arrogant violence, desiring a share in the kingship and committing other unholy acts]. See Gould 1989:43-55 for xenia and its obligations (e.g. reciprocity) as one of the 'most powerful strands of connection which structure Herodotus' narrative'; Fisher 2002:199-224 for popular morality in Herodotus.

40 West 1985:288. For a failed Spartan attempt to establish a colony in Libya, in the wake of their ancestor (Theras), see Herodotus' account of the expedition of Dorieus, the halfbrother of the Spartan king, Cleomenes I (5.42-43). The Theraean colonists acted as their kinsmen's guides.

${ }^{41}$ Herodotus gives a detailed account of Theras' genealogy: a descendant of Polynices, son of Oedipus, on his paternal side, and an uncle, on his maternal side, to the sons of Aristodemus, presumably the hero of the First Messenian War in the $8^{\text {th }}$ century BCE (4.147). 
The fact that the island was eventually named Thera after him - that

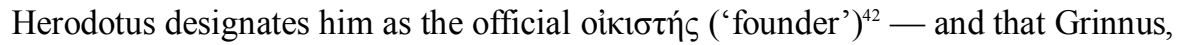
the Theraean king, who went to consult the oracle, whose response prompted the colonizing expedition to Libya, was a descendant of Theras (4.150), suggests that Theras, the colonist, eventually came to exert the very power (by fair means or foul) he was denied in Sparta.

Herodotus' celebrated account of Thera's colonization of Libya in the $7^{\text {th }}$ century BCE reveals, as many scholars have observed, most of the stock features of the narratives of early Greek colonization; what is striking is that Herodotus anticipates the structure of the colonization 'family' narratives of the 1820 settlers, but he gives us, whether intentionally or not, the perspectives of both the colonizers and the colonized, suggesting the range of polyphonic voices in both groups. In the following account, the sub-titles of each section suggest how Herodotus' colonization narrative both prefigures and differs from family settler histories of the arrival of the 1820 Albany settlers in South Africa.

\section{The colonizers as sources: Reasons for emigration}

He begins with the colonizers, indicating that they are the only source for the account which follows $(4.150,154)$. In other words, the notion of history written from the conqueror's (here the colonizer's) viewpoint, with all its inherent biases, would not have been strange to Herodotus. Accordingly, the colonizers, as if they were the only group involved in the colonization of Cyrene, ${ }^{43}$ justify their expedition with the religious authority of Delphi and Apollo, previously linked to Cyrene in Libya through the elaborate genealogy of Cyrene, daughter of the Lapith King, celebrated, along with the links between Apollo, Battus and the ruling dynasty, in three of Pindar's Pythian odes. ${ }^{44}$

Reminding us of the mixed ethnicity of the colonization of Thera itself, the Theraean account, ventriloquized by Herodotus, indicates that the delegation to Delphi consisted of the king, a descendant of Theras, and Battus, whose ancestry was Minyan. Although the pilgrimage was made for 'other things', the Pythia instructed the king to found a city in Libya. The king, Grinnus, rejected the

42 4.148.4. Earlier in his account (4.147.1), Herodotus uses another of the cognates

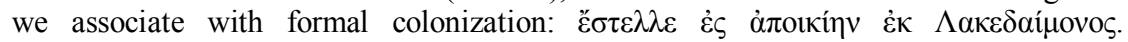
Anachronistically, of course (How \& Wells 1961:350).

43 Rather as the 1820 settlers are frequently presented in settlers' narratives as a uniform group identifying as white, Anglo-Saxon Christians (Protestant and Anglican), ignoring, for example, the Catholics and Jews amongst them.

44 Pythian 9.5-8, 52-58 (the genealogy and mythology of Cyrene); Pythian 5.60-62, 9093, 103-104 (the close links between Apollo and the Battiads); Pythian 4.1-8, 55-56, 59-69, 259-261 (Delphi's role in the foundation of Cyrene). 
oracle's response on the grounds of his old age and pointed at the younger Battus. The delegation then left Delphi and did not obey the oracle because, reasonably, they did not know where Libya was (4.150). ${ }^{45}$

Herodotus then implicitly, in the very next chapter, links this religious impiety with a seven-year drought, which was inflicted on Thera, and which prompted another delegation to Delphi. Once more the Pythia, who had a good memory, referred to the colony in Libya. The geographically-challenged Theraeans then sent out messengers to Crete, the largest and most developed island nearest to them, which would play an important role in the colony (4.161), to seek out anyone who had been to Libya. They found a murex-fisherman, Corobius, who informed them that winds had once driven him off course to a Libyan island, Platea (4.151). Hired as a guide, Corobius returned first to Thera and then set out with a small party of Theraeans who left him on Platea with food for a few months and returned to their home island with news of Platea (4.151).

At this point, Herodotus, ever eager to interrupt his narrative with a human interest story, which reflects his interest in aetiology and ethics, introduces an account of how Corobius' plight, when his Theraean provisions ran out, was alleviated by the generosity of some Samian merchants, whose good deeds were duly rewarded by large profits in Tartessus, and whose piety was demonstrated by the erection of a large, expensive bronze votive offering in Hera's temple on Samos. ${ }^{46}$ The aetiology of the deep bonds of friendship between the Cyrenaeans, Theraeans and Samians is duly acknowledged (4.152); presumably the Theraean account, followed by Herodotus here, wanted to justify, as with the Cretans, the significant presence of Samians in Cyrene later (4.163-164), and underline the fact that Cyrene may have been in barbarian Libya (Africa), but maintained connections to its Greek roots. Frogs around a pond indeed.

45 Fontenrose questions the veracity of all the oracles associated with the foundation and early history of Cyrene: 'Only Q46 and Q48 might be considered to be derived from an actual Delphic sanction of a Theraean colonial enterpreise in Libya; but as they stand they are part of a dubious narrative' (1978:120). Q46 (Herodotus 4.151.1) and Q48 (Hdt. 4.156.2) are categorized by Fontenrose as 'quasi-historical responses' (i.e. claiming to be historical, ibid. 283-284). For a trenchant (and amusing) critique of Fontenrose's hardline scepticism and his arbitrary oracular categories, see Hart 1982:183-186. The connection between Delphi and Cyrene was a strong one: rich Cyrene became one of its 'best clients' and Delphi may well have provided an 'oracular background' for its colonization (ibid. 41-42).

46 Herodotus' pro-Samian bias has often been noted (How \& Wells 1961:3, 30; Asheri et al. 2007:3). 


\section{The composition of the settlers: Socio-economic class}

When Herodotus returns to his colonization narrative, he immediately focuses on the Theraean decision to send out the colonizing party to Platea in accordance with a specific resolution: to choose by lot one of a pair of brothers from each of the seven regions and to make Battus both leader and king of the party of men, ${ }^{47}$ which set out for Platea in two fifty-oared ships. This final section of the Theraean-only source suggests, perhaps, an important reason for the colonizing expedition: the need to trim down, in families on Thera, the numbers of brothers, who could inherit land, in a small and rather barren island. Furthermore, the resolution confirms what the traditional account remembers as the fairness of the Theraean political system - the kingship - which will be perpetuated in the colony and implies that the party of men only will have to marry indigenous Libyan women to survive.

\section{The colonists (settlers) and colonized (the Libyans) as sources}

At this point, Herodotus acknowledges that what follows is in agreement with both Theraean and Cyrenaean sources, and immediately qualifies this with an alternative biography of Battus, found only in Cyrenaean sources. This suggests that the descendants of the original Theraean colonists, once they had intermarried with Libyan women in Cyrene, devised a fictionalized account of the ancestry of their founder, which has all the elements of the mythological origins of a Greek

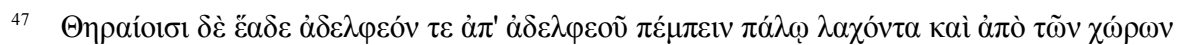

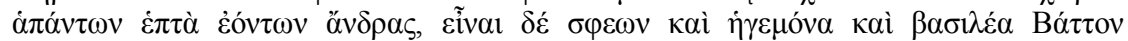
(4.153.8-11) [The Therans decided to send out men, one from each pair of brothers chosen by lot from the seven districts, and to make Battus the leader and king of this party]. In that section of the $4^{\text {th }}$ century Cyrene inscription, which claims to be an original $7^{\text {th }}$ century decree of the Theraean ekklesia (lines 23-40), there are some striking similarities to Herodotus' account of the colonization: the role of the oracle of Apollo (24), the sending of Battus as 'founder' and king (26-27) and the party's composition of hetairoi sailing on fair and equal terms according to household, choosing one son (27-29). The inscription is then illegible, but continues with sections, which assure later arrivals from Thera of their right to portions of unoccupied land (30-33), indicate on what terms the colonists can return to Thera (33-37) and specify the penalties for ignoring these terms (37-40). The inscription concludes with a curse reinforced by the performance of a binding act of magic (40-51). (Meiggs \& Lewis 1969:5-9). The editors, despite the problems the form of the decree and the language present, 'prefer to assume a long and complex moulding of a genuine original within the tradition of Thera ... and think it not unsafe to assume that we have before us genuine elements of what was said and done in seventh-century Thera' (ibid. 9). Cf. Malkin 2003:166-167. For doubts about the decree's authenticity, see Asheri et al 2007:680. 
founding hero, thus both glamorizing and legitimizing the Battiad dynasty and Greek presence on Libyan (African) soil. ${ }^{48}$

\section{Voyage, arrival, privations of the colonists}

After this entertaining alternative biography of Battus-Aristoteles, Herodotus does not rehearse the Theraean-only source material about disobeying the oracle and the resultant seven-year drought on Thera, but succinctly indicates there were unspecified misfortunes on Thera, which resulted in a return pilgrimage to Delphi, and a further confirmation of the need to establish a colony in Libya, which would be 'better' for the Theraeans. Furthermore he introduces important material, perhaps from the Cyrenaean Greek source, not in the Theraean-only source: the colonists went to Libya, then returned in despair to the mother island, only to be met by stones flung at them from the Theraeans, which forced them to go back and plant a colony on Platea (4.156).

After two years on the island without success, the hapless colonists again returned to Delphi only to be met with a response which claimed that the god had seen the sheep-rearing pastures of Libya, as a result of which the Theraeans transferred their settlement from the island to the mainland of Libya itself, to a fertile place named Aziris, where they lived for six years (4.157-158).

The indigenous peoples, expansion, the land question, and settler-indigenous conflict

At this point Herodotus introduces us to the Libyan people themselves and midway though his narrative claims that he did consult Libyan sources (presumably oral, 4.173): significantly, the first recorded encounter between the settlers and the indigenous people (in the seventh year!) is about land. They persuaded the Greeks to abandon Aziris (with its lovely groves and river), promising to show them a 'better' place and took them further west. Cunningly, the Libyans made the colonists pass through the finest section of country (Irasa) in the dark so they would not see it, until they reached a spring called Apollo's Fountain, where the

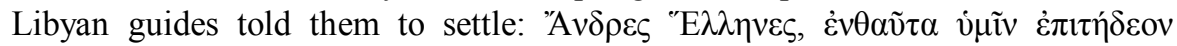

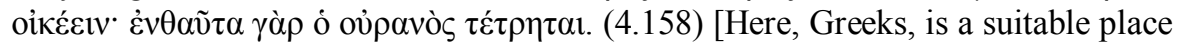
for you to settle: for here the sky has been perforated]. ${ }^{49}$ This then became the

48 For this alternative biography which has all the features of a rollicking Greek novel, see Herodotus 4.154-155. Glamorizing and legitimizing the Greek dynasty on African soil had already been attempted by Pindar (see note 44 ).

49 Presumably a reference to the heavy winter rainfall in Cyrene. See Asheri et al. 2007:686; for another interpretation, see How \& Wells 1961:353. One of the Akroterion 
colony of Cyrene, the name being derived from an alternative name of the spring (Kú $\uparrow) .{ }^{50}$ Significantly, the fertility of Libya and the beauty of the city of Cyrene itself had already been celebrated in Pindar's Pythian odes and was clearly a feature of a performative oral tradition. ${ }^{51}$

To the land issue and the response of the indigenous peoples, Herodotus immediately adds the colony's expansion and the increase in the numbers of Greek settlers, claiming that for the first fifty six years, under the founder Battus and his son Arcesilaus, the population of the colony was stable, until, during the reign of Battus II, yet another extraordinary oracle at Delphi exhorted all Greeks to settle in Libya in response to a Cyrenaean invitation which promised land. ${ }^{52}$ This influx of Greeks, who seized a great deal of land from the neighbouring Libyans, precipitated the first major conflict between the Greek settlers and the indigenous peoples, who asked the Egyptian pharaoh, Apries, for help: he sent an army against the Cyrenaeans who defeated the Egyptians heavily at Irasa/Thestes (4.159). ${ }^{53}$

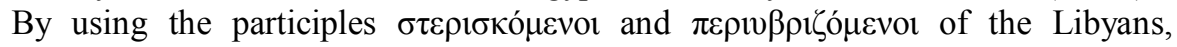
'robbed' of their land and 'aggressively maltreated' by the Cyrenaeans (4.159), Herodotus reveals that, as far as the expansionism and land-grabs of the colonizers were concerned, he was either on the side of the indigenous Libyans or was using pro-Libyan oral traditions, or perhaps both.

\section{Establishing the dynasty: Settling in}

Herodotus not only gives an account of the tensions between the Cyrenaeans, the Libyans and the Egyptians, but as he charts the careers of descendants of Battus II in subsequent chapters of Book Four, he focuses on tensions within the ruling family and on the expedient alliances made between family members and the indigenous Libyans: squabbles between Arcesilaus (Battus II's son) and his brothers resulted in the secession of his brothers, who then founded the city of

readers suggests that the odd Greek expression could suggest verbal interaction with the indigenous Libyans.

50 Ibid. 1961:353; for the possibility of a Libyan origin for the name, see Asheri et al 2007:683.

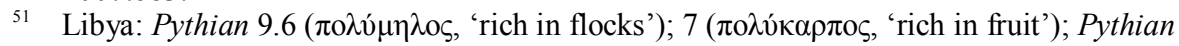

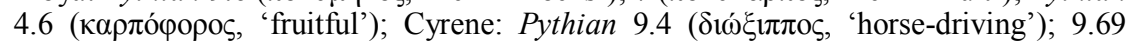

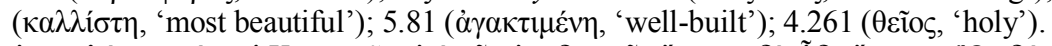

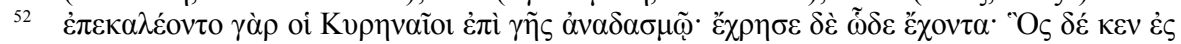

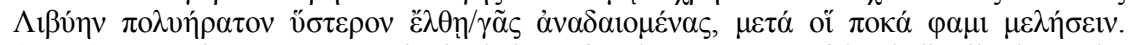
(4.159). [For the Cyrenaeans invited them for the purposes of land distribution. The words of the oracle were as follows: "Whoever comes later to the much-loved land of Libya, once the land has been distributed, I declare will then regret his action'].

53 How \& Wells 1961:353. Under Battus II in 570 BCE (assuming that Eusebius' date for the foundation of Cyrene in $631 \mathrm{BCE}$ is accurate); cf. Asheri et al 2007:686. 
Barce, ${ }^{54}$ and induced the Libyans to revolt from the Cyrenaeans. Arcesilaus then led his army against the Libyans who, in their flight, led him to Leucon, where, in a subsequent battle, the Libyans inflicted a heavy defeat on the Cyrenaeans (4.160).

After this defeat of the colonizers by the indigenous peoples, Herodotus charts the final decline of the Battiad dynasty and the monarchy the founding fathers had brought with them. After the murders of Arcesilaus and his brother, who had strangled him, and the accession to the kingship of the lame Battus III, the Cyrenaeans, as in previous difficulties, sent to Delphi to ask what sort of political constitution would result in the greatest prosperity for them.

The Pythia ordered them to fetch a Mantinean $\kappa \alpha \tau \alpha \rho \tau 1 \sigma \tau \tilde{\eta} \rho$ (a mediator), who turned out to be the distinguished Demonax, who came to Cyrene and divided the Cyrenaeans into three tribes: one for the Theraeans and $\pi \varepsilon p$ íoukol, one for the Peloponnesians and Cretans, and one for all the islanders. He also curtailed the powers of the king by restricting the number of temple precincts and priesthoods he could possess, and awarded the rest to the people (4.161). Thus three problematic areas in the aftermath of colonization, certainly ever present in narratives of British colonization in South Africa - a political constitution for the ruling elite and restrictions on power and wealth - were determined and thus legitimized by a Delphic appointee, who excluded the indigenous Libyans, unless

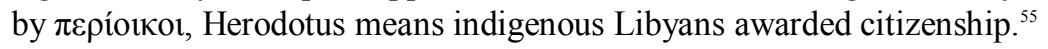

The remainder of Herodotus' narrative of the fate of the Battiad dynasty follows a predictable pattern of 'decline and fall', in which, notably, the binary, vicious Persian monarchic aggressor and noble Greek 'democratic' victim, is further subverted: the rejection of the reforms of Demonax by Battus III's son, Arcesilaus; the defeat and subsequent flight of the factional royal party to Samos (4.162); the return of Arcesilaus to Cyrene at the head of soldiers to whom he had promised Libyan land; Arcesilaus' revenge on the revolutionary faction; the exile of some Cyrenaeans and, finally, the assassination of Arcesilaus in Barce by, amongst others, some of these very exiles $(4.163,164)$.

${ }^{54}$ West of Cyrene 'on the high ground on the east coast of the Syrtis' (How \& Wells 1961:354; Asheri et al 2007:689).

55 Who the $\pi \varepsilon$ píoikot were is a matter of scholarly speculation: the slaves of the Theraean colonists, or indigenous Libyans given citizenship (How \& Wells 1961:355) or 'natives' who took part in the colonization, Greek clients of Theraean origin, or the aristocracy from the first colonists (Asheri et al 2007:690). I prefer Libyans given citizenship. After all, the Libyans had defeated the Cyrenaeans in battle: excluding them completely from political power would have been very dangerous. 
In this narrative, Herodotus manages to include yet another Delphic oracle, the misinterpretation of which resulted in Arcesilaus' murder $(4.163,164),{ }^{56}$ and his meddling mother (Pheretime), whose military ambitions transgressed genderrole norms (at least on Cyprus) (4.162). ${ }^{57}$

In Arcesilaus' absence at Barce, his mother assumed regency in Cyrene, but, when she learned of her son's death, she (a medizing Greek!) fled to Egypt to throw herself upon the mercy of the Persian viceroy, Aryandes, who had been appointed by Cambyses (Cyrus' son), to whom Arcesilaus had given Cyrene and arranged to pay tribute..$^{58}(4.165,166)$. Aryandes, perhaps swayed by Pheretime's claim that Arcesilaus had been assassinated because of his 'medizing' (4.165), put an army and navy at her disposal, in response to her request for vengeance, not before Aryandes had learned from the Barcaeans that they all took responsibility for the murder of Arcesilaus. Even though this was the pretext for dispatching these forces, Herodotus thinks that the Persians sent out these troops to subdue Libya, which had not completely surrendered to the Persian king (4.167).

\section{The indigenous peoples of Libya}

What older commentators, such as How and Wells (1961), regard as a 'long digression on Libya' (4.168-198), which now 'interrupts' the History of Cyrene (1961:354),$^{59}$ I would like to regard as the kind of essential focus on the indigenous

56 Once more a member of the Battiad dynasty went off to consult the Delphic oracle and the Pythia's reply, obviously concocted post eventum, predicted that the family would rule Cyrene for eight generations: with typical Delphic obscurity, the oracle also warned Arcesilaus, on pain of death, 'not to bake the amphorai in the oven or, if he did, not to go to a place surrounded by the sea'. Predictably, Arcesilaus set fire to a tower of Cyrenaean refugees (the amphorai in the oven) and imagined Cyrene, rather than Barce, to be the 'place surrounded by the sea'. See Baragwanath 2020:168-171.

57 When Arcesilaus fled to Samos, his mother went to the ruler of Salamis in Cyprus to ask for an army to restore Cyrene to her son (and herself): the ruler (Evelthon) refused her request, finally giving her a golden spindle, distaff and wool, adding that these, not armies, were gifts for women (4.162). For the role of the Greek Pheretime and female agency within the wider context of Herodotus' work, see Baragwanath 2020:162-176.

58 In 3.13, Herodotus refers to the surrender to the Persians of the Libyans and the peoples of Cyrene and Barce, who sent tribute to Cambyses: Cambyses was pleased by the Libyan tribute, but so displeased by the smallness of the Cyrenaean contribution (500 silver minae) that he tossed it amongst his troops. There is no mention of this incident in Book 4. As How \& Wells note, 'H. has not harmonized his two sources, and Cyrenaic tradition clearly slurred over the fact of submission to Persia' (1961:356).

59 Not an interruption for the author. As he openly admits earlier in Book 4, when expressing his amazement at the absence of mules in Elis (whilst on the subject of

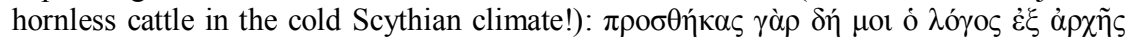
$\dot{\varepsilon} \delta i \zeta \eta \tau o ~(30)$ [for from the beginning, my work (history) has searched for supplementary 
peoples so often ignored, as we have seen, in modern settler accounts of colonization in South Africa. Significantly, Herodotus frames this essential 'digression' by reiterating the claim that the majority of the many and diverse Libyan peoples ( $\varepsilon v \varepsilon \varepsilon \alpha)$, together with their kings or chieftains, had not surrendered to Darius $(4.167,197)$. It is thus Herodotean endorsement of Libyan resistance to the imperial colonizer (Persia) which frames the second of his ethnographies in Book Four. What of Libyan resistance to the Greek colonists?

Herodotus' account of the indigenous peoples of Libya, ${ }^{60}$ both nomads and those settled in communities, coastal and inland dwellers, from those nearest Egypt in the east to mysterious peoples in the west beyond the Pillars of Hercules, is characterized by many of the 'topoi' we associate with the construction of the nonGreek 'other' in his accounts of the Egyptians and Scythians - reversals of the natural physiognomic and gender order ${ }^{61}$ and unGreek marital practices, marked by promiscuity and cruelty to children. ${ }^{62}$ Incorporating mythological peoples in the narrative, such as Homer's Lotus-Eaters (4.177) and distinguished visitors, such as Jason, who had experienced a divine encounter in Libya (4.179), and the Trojans (4.191), contributes not only to the exotic charm of Libya, but also to its association with the cultural heritage of the colonizers. The latter two examples are especially significant for any history of colonization. Herodotus uses the Jason episode to reveal Libyan resistance to the proposed mass Greek colonization of the shores of Lake Triton. The reference to the Trojans suggests how the vermilionstained, non-nomadic Maxyes constructed their genealogy in relation to foreign heroes and warriors who were vanquished enemies of the Greeks, driven into nomadic exile.

However, what makes this 'digression' an important feature of any colonization narrative, notably absent in the 1820 settler history we examined earlier, is what Luraghi deems Herodotus' meta-historiē: the fact that the historian

information]. As the roots of $\pi \rho \circ \sigma \theta \eta \dot{\kappa} \alpha \varsigma$ suggest, Herodotus 'adds to' rather than 'wanders away from'! See LSJ, s.v. $\pi \rho \circ \sigma \theta \eta \dot{\kappa} \eta$.

60 Probably Hecataean (Asheri et al 2007:568-569).

${ }_{61}$ For instance, dog-headed men and the headless with eyes in their chests in the wooded and mountainous areas west of the Triton river (4.191); masculine, militarized women, reminiscent of the Amazons in the Scythian half of Book 4 (110-116), such as the warrior maidens of the Machlyes and Auseans (4.180) and the chariot-driving warrior women of the Zauekes (4.193). Cf. the peoples in Scythia and its neighbouring territories with lycanthropy amongst the Neuri (4.105) and, predictably, cannibals (4.106).

62 For brides shared sexually on her first night with all the men in the wedding party, see the polygamy of the Nasamones (4.172); for the validation of female sexual promiscuity, see the anklet-wearing women of the Gindanes (4.176); for cruelty to children amongst many Libyan nomads, see 4.187. 
claims to have consulted the Libyans and Carchedonians themselves about their own histories, peoples and social practices $(4.173,180,187,191,195-196) ;{ }^{63}$ he uses ö $\psi 1 \varsigma$ to corroborate an aspect of Carchedonian mining practice (4.195) and even manages to use a Libyan word for a type of indigenous mouse (4.192). Reminding the audience how he reflects on his methodology, on the very process which shaped his history, Herodotus uses his customary incredulity formula twice to convey his doubts about some Libyan child-rearing practices and their fabled health (4.187); ${ }^{64}$ furthermore he questions the veracity of Carchedonian claims about extracting gold-dust from mud with pitch-smeared feathers (4.195).

Herodotus, however, also constantly reminds his audience what resources Libya had to offer the colonizer (and why it turned out to be worth colonizing): the silphium, which eventually became the staple of the Cyrenaean economy (4.169) ${ }^{65}$ dates (4.172), the olives and vines on the island of Cyrauis (4.195), the cornfields and well-watered black soil of Cinyps (4.198), the abundant fertility of the area around the colony of Cyrene itself with its eight-month harvest (4.199) and, of course, the horses required for the four-horse chariots $(4.170,183)$, which Herodotus thinks the Libyans taught the Greeks how to use (4.189). Furthermore, and perhaps more significantly, Herodotus thinks that the dress of Libyan women inspired the robe and aegis of statues of Athene and that the Greek ritual cry of the ololuge originated in their chants (4.189) ${ }^{66}$ Suggesting that two iconic features of Hellenic civilization - statues of Athene and the ritual cry during sacrifices may well have been derived from Libya (Africa) immediately prods the audience

63 Just as he uses the accounts of the Scythians and the Pontine Greeks in the first half of Book 4 (7-8, 12-13). Later he notes discrepancies in the accounts of Aristeas and the Scythians $(4.24,95)$.

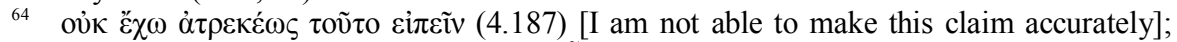

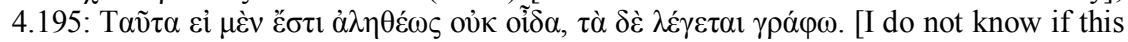

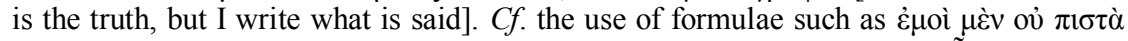

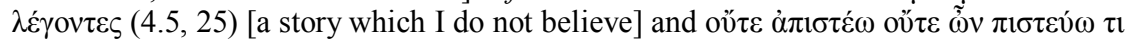
$\lambda i ́ \eta v(4.96)$ [I neither disbelieve nor fully believe] in the Scythian section of Book 4. When he does know, Herodotus is especially confident $(4.33,34)$.

${ }^{65}$ For silphium, its appearance on coins and the Cyrenaean economy, see How \& Wells 1961:357; Asheri et al 2007:696-697.

66 Dismissed with disdain by How \& Wells (1961:364-365), who reject Herodotus' 'worthless' etymological 'argument', and consider his 'resemblances' between the dress of Libyan women and the Palladia as 'purely accidental'. Contra Bernal in Black Athena (1987) who, seduced by Herodotus' diffusionism, uses Herodotean exempla such as these to construct his hypothesis about the 'Afroasiatic roots of Classical Civilization'. Cf. Asheri et al 2007:701-703; 711-712. 
into interrogating whether the 'othering' of the Libyans as unHellenic barbarians can ever be justified. ${ }^{67}$

\section{The fate of the Greek colony}

The remainder of the colonization narrative concentrates on the tragic end of the Greek dynasty in Africa and the Pyrrhic victory of the Persians, who resorted to barbarian practices, such as enslavement, not attempted by the Greek colonists from Thera. Aryandes' army arrived from Egypt and laid siege to Barce for nine months, in which they had to resort to digging underground passages (4.200); after heavy losses on both sides, the general (Amasis) tricked the Barcaeans into leaving their city and opening their gates in order to negotiate a bogus peace treaty, as a result of which the Persians took the city (4.201).

Pheretime's revenge on the killers of her son was cruel and violent (4.202); the Persians enslaved the Barcaeans, who were not of the royal house of Battus and accomplices in the murder, and marched on the city of Cyrene, which permitted the army to enter, thus fulfilling yet another oracle (4.203).

When Herodotus moves on to the Persian campaign against the city of Cyrene itself, he presents the reader with an argument between the Persian commander of the fleet and commander of the infantry on land. The admiral wanted the city to be captured, but the general replied that Barce was the only Greek city he had been ordered to attack (4.203). ${ }^{68}$ The Persians then regret their decision not to enter the city; the Cyrenaeans refuse, of course, and the Persians return to Egypt, having endured an attack by the indigenous Libyans, who, notably, killed and robbed the stragglers. ${ }^{69}$

${ }^{67}$ For Herodotus' interrogation of the binary Greek/barbarians in Book 4, see Baragwanath 2020:176-179. Some of the Libyan tribes were obviously already Hellenized (4.170, 171).

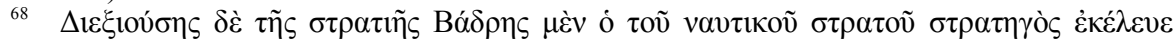

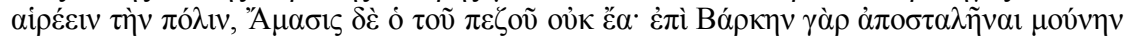

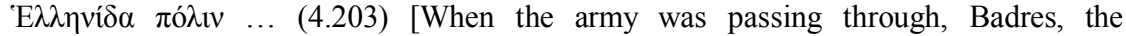
commander of the fleet, wanted the army to take the city, but Amasis, the general of the land forces, would not permit this, saying that Barce was the only Greek city he had been sent against].

${ }^{69}$ Although the Persian forces regretted not capturing Cyrene and attempted to enter it again, the Cyrenaeans kept them at bay and, eventually, the Persian army returned to Egypt at the behest of Aryandes (4.203). Darius awarded the enslaved Barcaeans a town in Bactria (subsequently named Barce as well) (4.204), and the vengeful Pheretime (daughter of Battus, wife of Battus III; How \& Wells 1961:369) returned to Egypt where she died a suitably horrible death — especially designed for those who opt for vengeance of an especially gruesome kind (4.205). 
Cyrene is clearly considered a Greek city as well. Is Herodotus subtly, through a Persian voice, returning to his Greek-Persian, Hellenicity-barbarian binary as he approaches the end of this account, ${ }^{70}$ or has he simply lost his way in the 'messy, multisided histories' of the colonization of the city and its aftermath? The retreat and defeat of the Persians may well reflect Herodotus' post-Battiad Cyrenaean sources, anti-tyrannical and anti-Persian, especially as another source, Menecles of Barce, claims that Pheretime defeated the Cyrenaeans with Persian help and placed her grandson Battus IV on the throne. ${ }^{71}$

\section{Conclusions}

This is highly likely, and indicative too of the fact that the 'source problem' in the historiography of colonization often involves separating the discursive (here the propaganda) and the factual, which is often so deeply mired in ideology that cleavage between the discursive and material becomes impossible. Herodotus' famous 'discovery' of cultural relativism, ${ }^{72}$ with reference to the striking exemplum of post-mortem parental cannibalism (3.38), indicates that the concept of the very subjective nature of the sources themselves occurred to him: when about to write his biography of Cyrus in Book 1, Herodotus concedes that he knows of four versions of Cyrus' life, but will choose a Persian version which does not glorify him but which tells the truth (1.95).$^{73}$ Furthermore, he is not afraid, as we have seen, to express his misgivings about the credibility of some of his oral sources $(7.152) .^{74}$

Even though thinking of this kind seems to me to characterize perceptive historical analysis, ${ }^{75}$ Herodotus is not consistently analytical and some scholars

70 For Herodotus' criteria for Hellenicity, see Hall 1989:172, 177, 181, 190. Cf. Cartledge and Greenwood 2002:351-371.

71 Corcella in Asheri et al 2007:720. Cf. How \& Wells 1961:369, ad loc.

72 The word is Edith Hall's (1989:186).

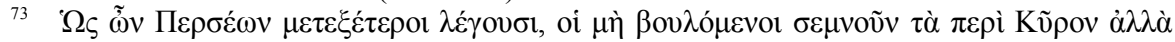

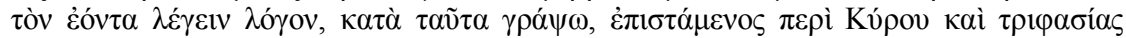

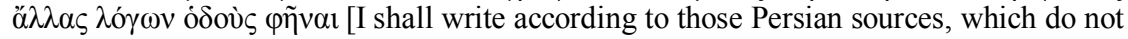
intend to embellish accounts of Cyrus but tell the story of his life as it is, in the understanding that three other accounts of his life tell a different story]. See Asheri et al. 2007:22.

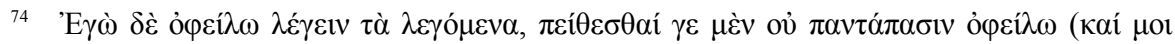

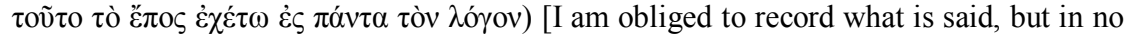
way obliged to be convinced by every detail (let this principle guide my entire work)].

75 See Dover 1988:44 for what he regards as the "truly original elements in the work of the pioneers of Greek historiography'; cf. How \& Wells vol. 1 1961:32-47. 
have argued that his thought smacks of the mythological. ${ }^{76}$ In, for example, Sourvinou-Inwood's structuralist analysis of Herodotus' version of the relationship between the tyrant of Corinth, Periander, and his hapless son, Lykophron, which culminates in a ritual on the island of Samos, ${ }^{77}$ she argues that the story, structured 'by an initiatory ritual schema serves as an aition for an initiatory rite' (1991:250). Believing that myths are structured by such schemata, Sourvinou-Inwood suggests that the Herodotean narrative is not an historical text, but a mythological one, the 'product of mythopoeic creation' (ibid. 261). Events which may 'appear' historical or 'purport' to be so are, in her opinion, 'an integral part of narrative nexuses which are versions of the mythological schemata structuring the text' (ibid. 262). ${ }^{78}$ In short, Herodotus, 'operating through the same mythological patterns as those which had structured any earlier forms of the narrative, which may have existed' may have contributed to the creation of his version in Book 3 (ibid. 267).

This may well be the case, but narratives of this kind, whatever their 'mythopoeic' pedigree, reveal just how interesting Herodotus' historiography is. If, as Sourvinou-Inwood believes, myths are polysemic and are structured by schemata and 'messages' 'reflecting important facets of the society's beliefs, realities, and representations' (1991:247), then they constitute the discursive elements which any respectable postcolonial historian would consider essential to historical analysis. Furthermore, the thought-world (the mentalité) of a predominantly oral culture does not exhibit the kind of linear logic of a text-based culture in which the written word predominates. What is lacking in Herodotus is a rigorous deconstruction of these 'mythopoeic' elements and the rhetorical tricks they deploy. However, in his account of the colonization of Cyrene, read through the lens of 1820 settler historiography, which is not entirely a product of 'mythopoeic creation', ${ }^{79}$ we can detect the origins of postcolonial historiography.

76 How \& Wells 1961:32-36 are surprisingly good on Herodotus' awareness of historic and pre-historic periods and on his use (and misuse) of mythology.

77 Herodotus 3.48, 50-53.

78 The relationship between father and son in the Lykophron-Periander story, in which the son does not succeed the father, thus ending the Kypselid dynasty, is paralleled, Sourvinou-Inwood believes, in father-son hostility myths, such as the TheseusHippolytus myth, in which Hippolytos is the 'failed ephebe par excellence' (1991:254, cf. ibid. 252-261, 283, n. 123.).

79 I suspect that settler mythologizing about the heroic frontier existence and, conversely, myth-making about mighty warriors in the Xhosa oral tradition can be considered 'mythopoeic' (see, e.g. Laband 2020:268 for the Xhosa myth that Maqoma's favourite bull, Jingqi, swam from the homelands of the amaXhosa to Robben Island to rescue him and that both were shot and killed when the bull rode into the waves). See notes 9, 14 above. 
The 'cacophony of voices' is certainly there, but charting a hermeneutic pathway through these is still far off in the future.

\section{BIBLIOGRAPHY}

Armayor, O K 1978. Did Herodotus ever go to Egypt? Journal of the American Center in Egypt 15.59-73.

Asheri, D, Lloyd A, Corcella, A (eds. Murray, O \& Moreno, A) 2007. A commentary on Herodotus Books I-IV (Bks 1-4): Oxford: Oxford University Press.

Bakker, E J, De Jong I J F \& Van Wees, H 2002 (eds.). Brill's companion to Herodotus. Leiden: Brill.

Bakker, E J 2002. The making of history: Herodotus' Historiēs Apodexis. In Bakker, E J, De Jong I J F \& Van Wees, H (eds.), Brill's companion to Herodotus, 3-32. Leiden: Brill.

2006. The syntax of historiē: How Herodotus writes. In Dewald, C \&

Marincola, J (eds.), The Cambridge companion to Herodotus, 92-102.

Cambridge: Cambridge University Press.

Baragwanath, E 2020. History, ethnography, and aetiology in Herodotus' Libyan Logos. Histos Supplement 11.155-188.

Bernal, M 1987. Black Athena. The Afroasiatic roots of classical civilization. Vol.1. New Jersey: Rutgers University Press.

Boedeker, D 2002. Epic heritage and mythical patterns in Herodotus. In Bakker, E J, De Jong I J F \& Van Wees, H (eds.), Brill's companion to Herodotus, 97116. Leiden: Brill.

Brown, D 2006. Voicing the text. South African oral poetry and performance. Oxford: Oxford University Press.

Cartledge, P \& Greenwood E 2002. Herodotus as a critic: Truth, fiction, polarity. In Bakker, E J, De Jong I J F \& Van Wees, H (eds.), Brill's companion to Herodotus, 351-371. Leiden: Brill.

Chamberlain, D 2001. 'We the others': Interpretive community and plural voice in Herodotus. CA 20.1:5-34.

Dewald, C \& Marincola, J 2006 (eds.). The Cambridge companion to Herodotus. Cambridge: Cambridge University Press.

Fisher, N R E 2002. Popular morality in Herodotus. In Bakker, E J, De Jong I J F \& Van Wees, H (eds.), Brill's companion to Herodotus, 199-224. Leiden: Brill.

Fontenrose, J 1978. The Delphic oracle. Its responses and operations with a catalogue of responses. Berkeley/London: University of California Press. 
Giangiulio, M 2001. Constructing the past. Colonial traditions and the writing of history: The case of Cyrene. In Luraghi, N, The historian's craft in the age of Herodotus, 116-137. Oxford: Oxford University Press.

Goldhill, S 1991. The poet's voice: Essays on poetics and Greek literature. Cambridge: Cambridge University Press.

Griffin, J 2006. Herodotus and tragedy. In Dewald, C \& Marincola, J (eds.),

The Cambridge companion to Herodotus, 46-59. Cambridge: Cambridge University Press.

Griffiths, A 2006. Stories and storytelling in the Histories. In Dewald, C \& Marincola, J (eds.), The Cambridge companion to Herodotus, 130-144. Cambridge: Cambridge University Press.

Gould, J 1989. Herodotus. London: Weidenfeld \& Nicolson.

Hall, E 1989. Inventing the barbarian. Greek self-definition through tragedy.

Oxford: Oxford University Press.

Hart, J 1982. Herodotus and Greek history. London/Canberra: Croom Helm.

Hornblower, S 2002. Herodotus and his sources of information. In Bakker, E J, De Jong I J F \& Van Wees, H (eds.), Brill's companion to Herodotus, 373-386. Leiden: Brill.

How, W W \& Wells, J 1961 [1912]. A commentary on Herodotus. Vol. I (Books IIV). Oxford: Clarendon.

Hude, C (ed.) 1975. Herodoti Historiae. Oxford: Clarendon.

Laband, J 2020. The land wars. The dispossession of the Khoisan and AmaXhosa in the Cape Colony. Cape Town: Penguin Random House.

Lambert, M 2020. The 1820 settlers bicentenary: A settler family's heritage. The Witness, $15^{\text {th }}$ May 2020, 7.

2021. Anthropology, comparative studies, and the Classics: Receptions of the 'savage' in the metropole and the periphery. AClass 64:1-34.

Luraghi, N 2001. The historian's craft in the age of Herodotus. Oxford: Oxford University Press.

2006. Meta-historiē: Method and genre in the Histories. In Dewald, C \& Marincola, J (eds.), The Cambridge companion to Herodotus, 76-91. Cambridge: Cambridge University Press.

Malkin, I 2003. 'Tradition' in Herodotus: The foundation of Cyrene. In Derow, P \& Parker, R (eds.), Herodotus and his world, 153-170. Oxford: Oxford University Press.

Meiggs, R \& Lewis, D 1969. A selection of Greek historical inscriptions. Oxford: Clarendon.

Pringle, T 1834. African sketches. London: Edward Moxon. 
Raaflaub, K A 2002. Philosophy, science, politics: Herodotus and the intellectual trends of his time. In Bakker, E J, De Jong I J F \& Van Wees, H (eds.), Brill's companion to Herodotus, 149-186. Leiden: Brill.

Romm, J 1998. Herodotus. New Haven / London: Yale University Press.

Rösler, W 2002. The Histories and writing. In Bakker, E J, De Jong I J F \& Van Wees, H (eds.), Brill's companion to Herodotus, 79-94. Leiden: Brill.

Saïd S 2002. Herodotus and tragedy. In Bakker, E J, De Jong I J F \& Van Wees, H (eds.), Brill's companion to Herodotus, 117-145. Leiden: Brill.

Snell, M 2004. On the Weymouth and beyond: The Pedlar family in South Africa. Kokstad (privately published).

Tallie, T J 2019. Queering colonial Natal: Indigeneity and the violence of belonging in Southern Africa. Minneapolis: University of Minnesota Press.

Thomas, R 2006. The intellectual milieu of Herodotus. In Dewald, C \& Marincola, $\mathrm{J}$ (eds.), The Cambridge companion to Herodotus, 60-75. Cambridge: Cambridge University Press.

Vansina J 1961. De la tradition orale. Essai de méthode historique. Tervuren: Musée Royal de l'Afrique centrale.

1985. Oral tradition as history. Madison: University of Wisconsin Press. 1994. Living with Africa. Madison: University of Wisconsin Press.

West, S R 1985. Herodotus' epigraphical interests. CQ 35:278-305. 2002. Scythia. In Bakker, E J, De Jong I J F \& Van Wees, H (eds.), Brill's companion to Herodotus, 437-456. Leiden: Brill. 